\title{
AEGIRINE AND RIEBECKITE OF THE ALKALI GNEISS OF PIKKUKALLIO IN THE HONKAMÄKI-OTANMÄKI REGION, FINLAND
}

\author{
KAI HYTÖNEN and TUULA HAUTALA
}

\begin{abstract}
HYTÖNEN, KAI and HAUTALA, TUULA, 1985: Aegirine and riebeckite of the alkali gneiss of Pikkukallio in the Honkamäki-Otanmäki region, Finland. Bull. Geol. Soc. Finland 57, Part 1-2, 169-180.

Aegirine and riebeckite coexist in a Precambrian peralkaline gneiss. Chemical analyses of the gneiss and chemical and physical data on the aegirine and the riebeckite are presented. The compositions of the two minerals are compared with those of other sodic pyroxenes and alkali amphiboles from Finland. The authors know of only two other occurrences in Finland where sodic pyroxene and alkali amphibole coexist. The riebeckite of the present study and the ferro-ferribarroisite of the adjoining Otanmäki are richer in iron and poorer in magnesium and calcium than the other known alkali amphiboles and sodic-calcic amphiboles from Finland. Zircon age of 2019 Ma has been obtained for a variety of the alkali gneiss of the region.
\end{abstract}

Key words: aegirine, riebeckite, chemical data, x-ray data, alkali gneiss, zircon age, Finland.

Kai Hytönen and Tuula Hautala: Geological Survey, SF-02150 Espoo, Finland.

\section{Introduction}

The alkali gneiss of this study has been described briefly in a paper on the granites of Honkamäki and Otanmäki by Marmo et al. (1966, cf. pp. 12-13 and 15, Table 2, photomicrographs Fig. 9 and Plate 1). The paper included an analysis of the rock, which was called alkali granite, and some optical data on the main femic minerals, aegirine and riebeckite.

Aegirine and riebeckite have since been analysed and studied by X-ray diffraction, and some trace elements of the rock determined. The present paper gives the results of these studies. Of the authors, Hytönen is responsible for the X-ray work, optical data and writing, and Hautala for the microprobe analyses.

\section{Material and methods}

The subject of the present study is a specimen collected in 1963, and numbered 7-OM for the study by Marmo et al. (op. cit.), from the northern slope of the Honkamäki hill, which is situated about $8 \mathrm{~km}$ west-northwest of the Otanmäki titaniferous iron ore deposit and mine (Fig. 1). Named Pikkukallio (Fig. 2) on the topographic map, the outcrop has the following coordinates: map sheet 3413 11, 
$\mathrm{x}=7115.75, \mathrm{y}=497.40$ or $64^{\circ} 08^{\prime} 28^{\prime \prime}$ ' North, $26^{\circ} 56^{\prime} 48^{\prime \prime}$ East.

The X-ray powder data were obtained with a Philips diffractometer, filtered Copper radiation. Silicon was used as the internal standard for aegirine and quartz for riebeckite. The microprobe analyses were conducted in 1975 using a Geoscan electron probe analyser with an accelerating potential of $20 \mathrm{kV}$ and a specimen current of 3-4 mA. The standards were hornblende (no. 35) and oligoclase (no. 44, for so- dium). The measured intensities were corrected using the Bence and Albee (1968) method.

\section{Alkali gneiss}

The rock of the Honkamäki hill in the Otanmäki region (Figs. 1 and 2) in the parish of Vuolijoki already drew some attention during the mapping of the general geological map of Finland. On map sheet C4 Kajaani (Wilkman

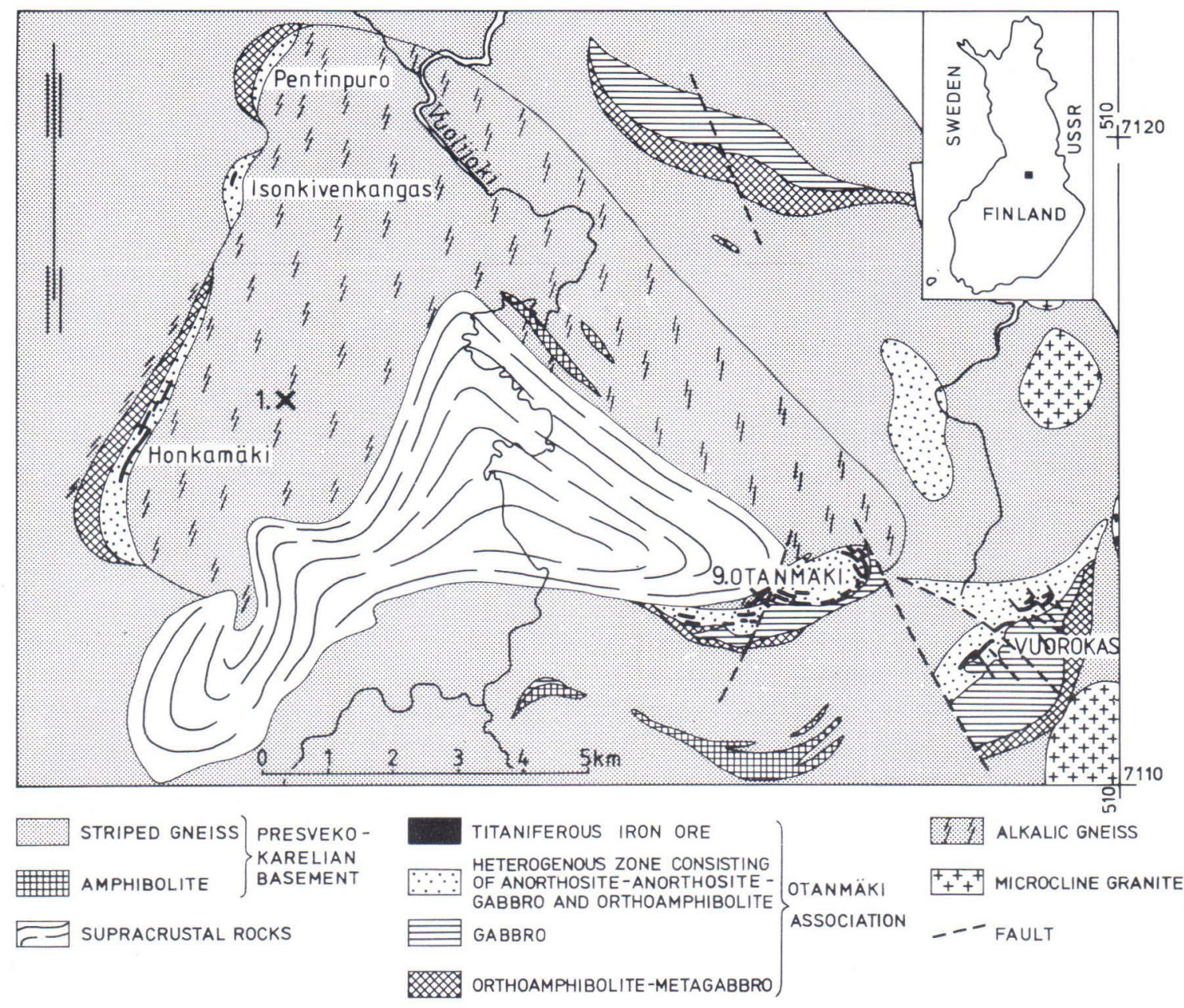

Fig. 1. Geological map of the Otanmäki region, according to Lindholm and Anttonen 1980. 1. Alkali gneiss of the present study (specimen 7-OM), containing aegirine and riebeckite. 9. Ferro-ferri-barroisite occurring as fissure fillings in alkali gneiss at the western foot of the Otanmäki hill (Hytönen and Heikkinen 1966). 


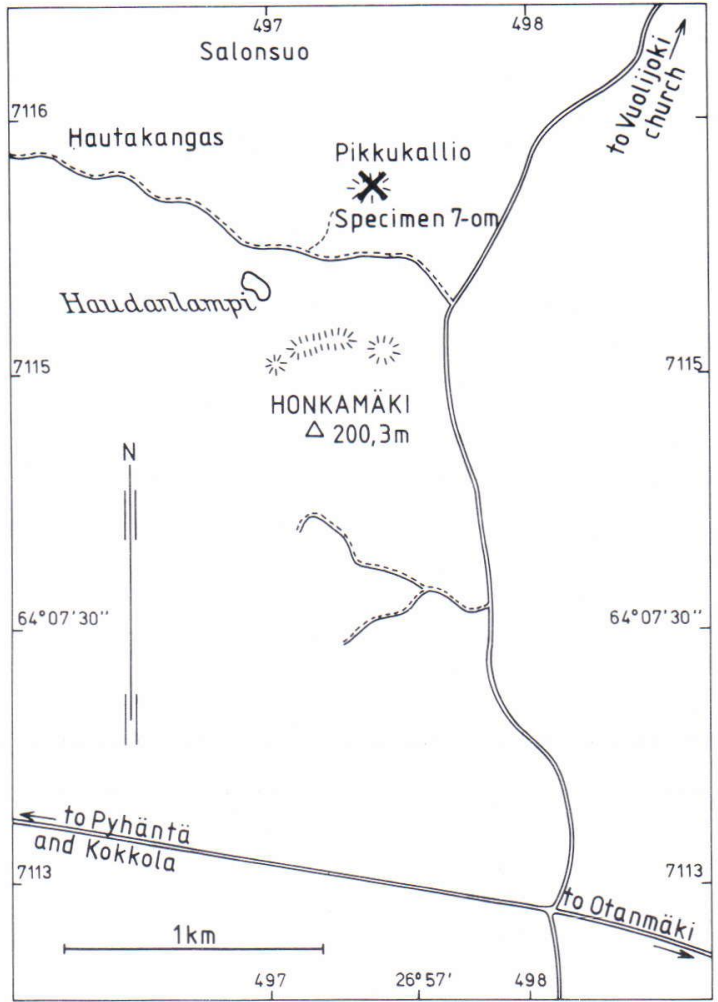

Fig. 2. Location of the alkali gneiss outcrop of Pikkukallio (cross, specimen 7-OM) on the northern slope of the Honkamäki hill.
Table 1. Alkali gneiss, 7-OM, Pikkukallio, Honkamäki, Vuolijoki. Chemical analysis, CIPW norm, Niggli numbers and modal composition.

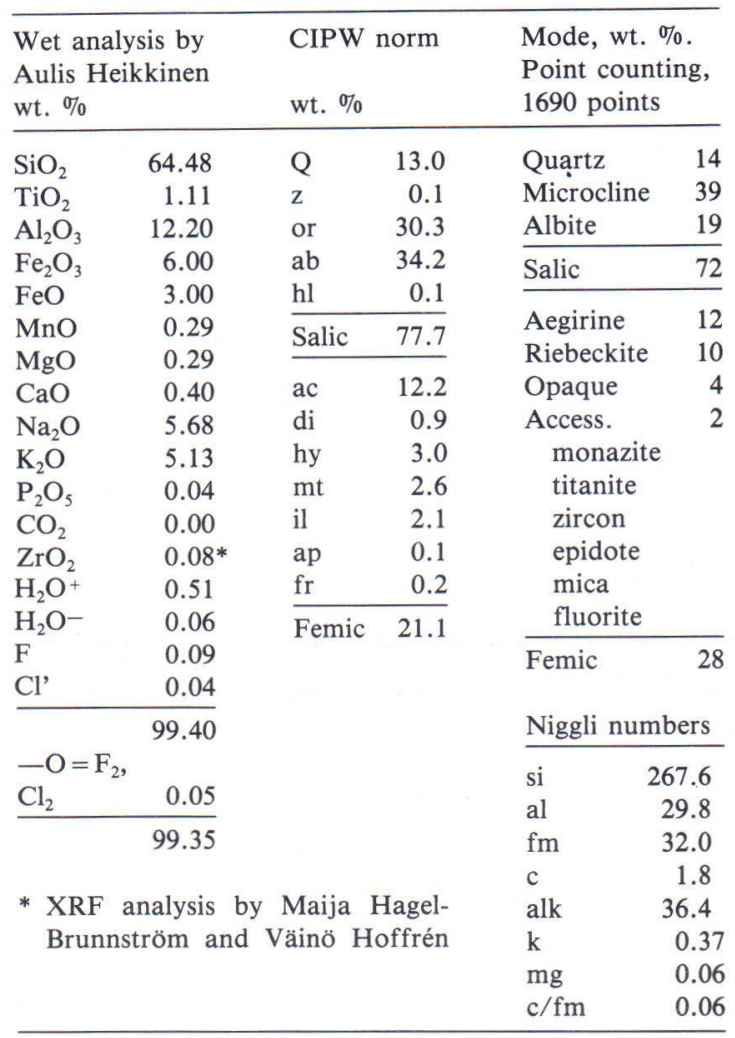

heterogeneous rock unit with metasomatic features».

In the present study the name alkali gneiss is used for compositional and textural reasons. If the rock is regarded as plutonic, the name microcline-albite quartz syenite should be used (Streckeisen 1974). The alkali gneiss is fine- to medium-grained (grain size $0.3-2.0 \mathrm{~mm}$ ) with distinct planar banding caused by alternating dark femic and reddish felsic streaks. Under the microscope the texture is weakly hypidiomorphic, in places slightly cataclastic, and the banding is only slightly detectable. The main minerals of the rock are microcline, albite, quartz, aegirine and riebeckite (Table 1). The microcline is cross-hatched (triclinicity 0.9 ) and perthitic. 
The albite is usually twinned, and some antiperthite can be seen. Both feldspars contain abundant opaque inclusions. Quartz has undulatory extinction. The femic constituents usually occur as irregularly shaped crystal aggregates, arranged into irregular bands. Among the accessories, monazite forms quite large grains, approximately $0.2 \mathrm{~mm}$ long. A qualitative microprobe analysis of the monazite gave: Ce, La, Nd, Pr, Sm (?), Gd and P.

Table 1 gives the chemical analysis, CIPW norm, mode and Niggli values of the alkali gneiss. The peralkaline character is portrayed by the presence of acmite, $\mathrm{NaFeSi}_{2} \mathrm{O}_{6}$, in the norm.

Table 2. Comparison of some trace element contents (ppm) of the alkali gneiss, 7-OM, Pikkukallio, Honkamäki, Vuolijoki with those of the granite averages of Taylor (1964) and felsic rocks (granites, granodiorites, etc.) of Vinogradov (1962).

\begin{tabular}{lccc}
\hline \multicolumn{2}{c}{ Alkali gneiss } & Taylor & Vinogradov \\
7-OM & & \\
\hline $\mathrm{Li}$ & $36^{1}$ & 30 & 40 \\
$\mathrm{Sc}$ & $<25^{2}$ & 5 & 3 \\
$\mathrm{~V}$ & $<13^{2}$ & 20 & 40 \\
$\mathrm{Ni}$ & $<15^{2}$ & 0.5 & 8 \\
$\mathrm{Cu}$ & $<15^{2}$ & 10 & 20 \\
$\mathrm{Zn}$ & $340^{1}$ & 40 & 60 \\
$\mathrm{Ga}$ & $60^{2}$ & 18 & 20 \\
$\mathrm{Rb}$ & $300^{3}$ & 150 & 200 \\
$\mathrm{Sr}$ & $16^{1}$ & 285 & 300 \\
$\mathrm{Y}$ & $90^{3}$ & 40 & 34 \\
$\mathrm{Zr}$ & $620^{3}$ & 180 & 200 \\
$\mathrm{Nb}$ & $110^{3}$ & 20 & 20 \\
$\mathrm{Mo}$ & $<10^{2}$ & 2 & 1 \\
$\mathrm{Ba}$ & $<100^{2}$ & 600 & 830 \\
$\mathrm{La}$ & $191^{4}$ & 40 & 60 \\
$\mathrm{Ce}$ & $315^{4}$ & & 100 \\
$\mathrm{Hf}$ & $22.9^{4}$ & 4 & 1 \\
$\mathrm{Ta}$ & $11.7^{4}$ & 3.5 & 3.5 \\
$\mathrm{~Pb}$ & $5^{2}$ & 20 & 18 \\
$\mathrm{Th}$ & $29.3^{4}$ & 17 & 3.5 \\
$\mathrm{U}$ & $4.5^{4}$ & 4.8 & \\
$\mathrm{Th} / \mathrm{U}=$ & 6.5 & & \\
\hline
\end{tabular}

AAS analysis by Meeri Wallgren

2 Optical spectrometric analysis by Ari Puisto

3 XRF analysis by Maija Hagel-Brunnström and Väinö Hoffrén

4 Instrumental neutron activation analysis by Rolf Rosenberg (Reactor Laboratory, Technical Research Centre of Finland)
Examination of Table 1 reveals that there is a difference between normative or and modal microcline, between normative ab and modal albite and between the sum of the normative femic silicates $(a c+d i+h y=16)$ and the sum of aegirine + riebeckite (22), which should approximately correspond with each other. The difference can be attributed partly to the difference in composition between the sample analysed (norm) and the thin section studied

Table 3. Aegirine, specimen 7-OM, Pikkukallio, Honkamäki, Vuolijoki. Chemical composition, numbers of ions on the basis of six oxygens, pyroxene end member composition and calculated densitity. 1. Average of four microprobe analyses $(\mathrm{FeO}=$ total iron); 2. Analysis of column 1 , done using the ratio $\mathrm{Fe}^{2+}: \mathrm{Fe}^{3+}=0.19$ (wet analysis); 3. Analysis of column 1, done using the values of $\mathrm{Fe}_{2} \mathrm{O}_{3}$ and $\mathrm{FeO}$ obtained in the wet analysis. Wet analyses by Pentti Ojanperä.

\begin{tabular}{|c|c|c|c|}
\hline & 1 & 2 & 3 \\
\hline $\mathrm{SiO}_{2}$ & 50.8 & 50.8 & 50.8 \\
\hline $\mathrm{TiO}_{2}$ & 0.3 & 0.3 & 0.3 \\
\hline $\mathrm{Al}_{2} \mathrm{O}_{3}$ & 1.3 & 1.3 & 1.3 \\
\hline $\mathrm{Fe}_{2} \mathrm{O}_{3}$ & & 29.1 & 27.1 \\
\hline $\mathrm{FeO}$ & 31.2 & 5.0 & 4.6 \\
\hline $\mathrm{MnO}$ & 0.5 & 0.5 & 0.5 \\
\hline $\mathrm{MgO}$ & 0.3 & 0.3 & 0.3 \\
\hline $\mathrm{CaO}$ & 3.3 & 3.3 & 3.3 \\
\hline $\mathrm{Na}_{2} \mathrm{O}$ & 11.5 & 11.5 & 11.5 \\
\hline \multirow[t]{2}{*}{$\mathrm{K}_{2} \mathrm{O}$} & 0.1 & 0.1 & 0.1 \\
\hline & 99.3 & 102.2 & 99.8 \\
\hline $\mathrm{Si}$ & & $1.94), 00$ & $1.97>200$ \\
\hline $\mathrm{Al}$ & & $0.06^{2.00}$ & $0.03,2.00$ \\
\hline $\mathrm{Al}$ & & & $0.03)$ \\
\hline $\mathrm{Ti}$ & & $0.01)$ & 0.01 \\
\hline $\mathrm{Fe}^{3+}$ & & 0.84 & $0.79\}_{102}$ \\
\hline $\mathrm{Fe}^{2+}$ & & $0.16>1.05$ & $0.153^{1.02}$ \\
\hline $\mathrm{Mn}$ & & 0.02 & 0.02 \\
\hline $\mathrm{Mg}$ & & 0.02 & $0.02 J$ \\
\hline $\mathrm{Ca}$ & & $0.13)$ & 0.14 \\
\hline $\mathrm{Na}$ & & 0.850 .99 & 0.861 .01 \\
\hline $\mathrm{K}$ & & 0.01 & $0.01)$ \\
\hline acmite & $\mathrm{NaFe}^{3+}$ & 84 & 81 \\
\hline jadeite & $\mathrm{NaAl}$ & - & 3 \\
\hline diopside & $\mathrm{CaMg}^{2+}$ & 2 & 2 \\
\hline hedenbergite & $\mathrm{CaFe}^{2+}$ & 10 & 10 \\
\hline \multirow[t]{2}{*}{ ferrosilite } & $\mathrm{Fe}^{2+} \mathrm{Fe}^{3+}$ & 4 & 4 \\
\hline & & 100 & 100 \\
\hline D calculated & & 3.61 & 3.59 \\
\hline
\end{tabular}


(mode), and partly to the fact that for the building of riebeckite some normative ab must be consumed and the perthitic microcline contains some of the normative $a b$, too.

In Table 2 some trace element contents of the alkali gneiss are given and compared with average contents in granites and felsic rocks from the literature. The alkali gneiss contains clearly higher Zn, Ga, Y, Zr, Nb, La, Ce, Hf and $\mathrm{Ta}$, slightly higher $\mathrm{Rb}$ and $\mathrm{Th}$, and much lower $\mathrm{Sr}, \mathrm{Ba}$ and $\mathrm{Pb}$ than the granites and felsic rocks; the contents of $\mathrm{Li}$ and $\mathrm{U}$ are about the same.

\section{Aegirine}

Table 3, column 1 gives the chemical analysis of aegirine, carried out by microprobe. The oxidation state of iron was determined by the wet chemical method on an aegirine fraction separated out of the rock (Table 3, columns 2 and

Table 4. X-ray powder pattern of aegirine from Pikkukallio, Honkamäki, Vuolijoki.

\begin{tabular}{|c|c|c|c|}
\hline hkl & I & $\mathrm{d}_{\text {meas. }}$ & $\mathrm{d}_{\text {calc. }}$ \\
\hline 110 & 59 & 6.39 & 6.38 \\
\hline 200 & 3 & 4.62 & 4.62 \\
\hline 111$\}$ & 82 & 4.41 & $\int 4.43$ \\
\hline 020 & & 4.41 & 4.41 \\
\hline 220 & 14 & 3.190 & 3.190 \\
\hline$\overline{2} 21$ & 83 & 2.985 & 2.986 \\
\hline 310 & 100 & 2.908 & 2.909 \\
\hline 131 & 19 & 2.547 & 2.549 \\
\hline 002 & 7 & 2.529 & 2.529 \\
\hline 221 & 35 & 2.480 & 2.481 \\
\hline 040 & 15 & 2203 & $\{2.205$ \\
\hline 112 & & & 2.203 \\
\hline 331 & 55 & 2.121 & 2.121 \\
\hline$\overline{4} 21$ & 26 & 2.097 & 2.097 \\
\hline 041 & 17 & 2.021 & 2.021 \\
\hline 241 & 11 & 1.938 & 1.937 \\
\hline 150 & 37 & 1.733 & 1.733 \\
\hline 531 & 39 & 1.613 & 1.613 \\
\hline 440 & 42 & 1.595 & 1.595 \\
\hline$\overline{6} 02$ & 31 & 1531 & $\int 1.531$ \\
\hline $350 J$ & 31 & 1.531 & 1.531 \\
\hline 060 & 6 & 1.470 & 1.470 \\
\hline 531 & 34 & 1.400 & 1.400 \\
\hline
\end{tabular}

$3)$. The total iron values of the microprobe and wet analyses differ slightly from each other (31.2 \% and $29.04 \%$ as $\mathrm{FeO}$, respectively). The difference can be attributed to the difference in both the analytical methods and the sampling. The microprobe analysis represents the average composition of four aegirine grains within a single thin section, whereas the wet analysis was done on a mineral concentrate of a few hundred milligrams. The two slightly different values for total iron are reflected as differences in the numbers of ions in the pyroxene formula, in the figures of the pyroxene end members and the calculated densities, as is shown in Table 3, columns 2 and 3 .

The following unit-cell parameters for aegirine were calculated from the powder pattern, listed in Table 4: $a=9.671$ (2) $\AA, b=8.820$ (2) $\AA$, $\mathrm{c}=5.292$ (1) $\AA, \beta=107.11^{\circ}, \mathrm{V}=431.4 \AA^{3}$.

The cell data obtained agree well with those given by Nolan (1969) for a synthetic pyroxene on the join acmite-hedenbergite with the composition $\mathrm{Ac}_{90.63} \mathrm{Hd}_{9.37}: \mathrm{a}=9.671 \AA \mathrm{A}, \mathrm{b}=8.820 \AA$, $\mathrm{c}=5.293 \AA, \beta=107.21^{\circ}, \mathrm{V}=431.22 \AA^{3}$. For the synthetic end member, pure acmite $\left(=A c_{100}\right)$, the following cell parameters are given (Nolan, op. cit.): $\mathrm{a}=9.658 \AA, \mathrm{b}=8.795 \AA, \mathrm{c}=5.294 \AA$, $\beta=107.42^{\circ}, V=429.1 \AA^{3}$.

The following optical properties were recorded: $\alpha$ (obs.) $=1.763$ (3), $\beta$ (calc. $)=1.799, \gamma$ (obs.) $=1.813$ (3), $2 \mathrm{~V}_{\mathrm{x}}=63^{\circ}$ (with universal stage), c $\Lambda \mathrm{X}=1^{\circ}-2^{\circ}$ (univ. stage); pleochroism: $\mathrm{X}$ green, $\mathrm{Y}$ green, $\mathrm{Z}$ yellowish brown; absorption $X>Y>Z$. The differences in the absorption between $\mathrm{X}, \mathrm{Y}$ and $\mathrm{Z}$ are small.

For comparison, the aegirine has been plotted on a diagram (Fig. 3) in terms of $(\mathrm{Na}+\mathrm{K}), \mathrm{Mg}$ and $\left(\mathrm{Fe}^{2+}+\mathrm{Mn}+\left(\mathrm{Fe}^{3+}\right)\right)$ together with some other aegirines, aegirine-augites and sodian diopsides from four other occurrences (nos. $2-5)$ in Finland. The localities are depicted on the map in Fig. 3. In the diagram the aegirine of the present study has been plotted using the averages of $(\mathrm{Na}+\mathrm{K}), \mathrm{Mg}$ and $\left(\mathrm{Fe}^{2+}+\mathrm{Mn}\right)$ from Table 3, columns 2 and 3. 


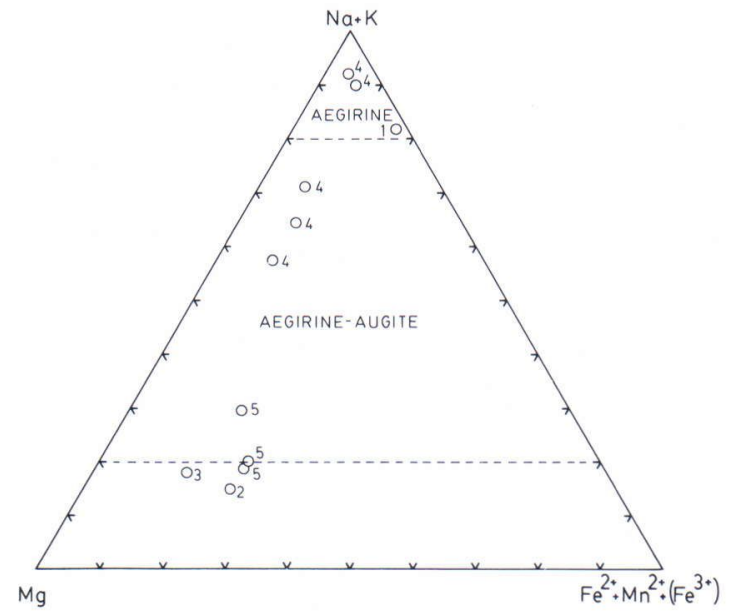

Fig. 3. Plot of aegirine of the present study (no. 1) together with other sodic pyroxenes from Finland in terms of $(\mathrm{Na}+\mathrm{K}), \mathrm{Mg}$ and $\left(\mathrm{Fe}^{2+}+\mathrm{Mn}+\left(\mathrm{Fe}^{3+}\right)\right)$. The components of the pyroxenes have been calculated following a proposal by Carmichael (1962). The last term $\left(\mathrm{Fe}^{3+}\right)$ is the excess, if any, of the trivalent iron over $\mathrm{Na}+\mathrm{K}$. The numbers of the plots refer to Fig. 4.

\section{Riebeckite}

Table 5, column 1 gives the microprobe analysis of riebeckite. The oxidation state of iron was determined by the wet chemical method from a riebeckite fraction separated out of the rock. The values for $\mathrm{Fe}_{2} \mathrm{O}_{3}$ and $\mathrm{FeO}$ obtained from the wet analysis were corrected for $7 \%$ aegirine (analysis in Table 3, column 3), occurring as impurity in the fraction. The total iron values of the microprobe and the corrected wet analyses differ from each other (37.1\% and $34.3 \%$, respectively). The difference can be attributed to the difference in analytical methods and sampling as in aegirine (page 173). The different values of total iron are reflected as differences in the numbers of ions in the amphibole formula and in the calculated densities (Table 5, columns 2 and 3). As the water plus halogen content was not determined, the standard amphibole formula was calculated on the basis of 23 oxygens according to the procedure recommended by the subcommittee on amphiboles of the International Mineralogical

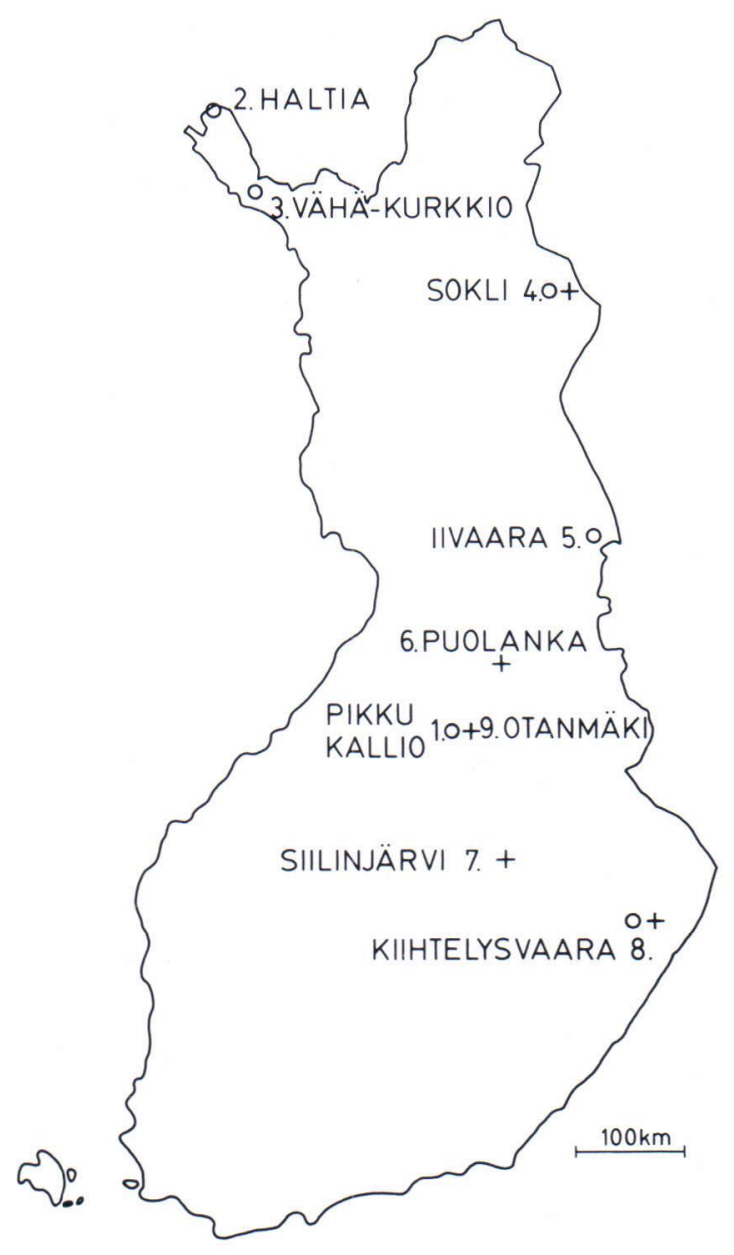

Fig. 4. Map of Finland showing the locations of the sodic pyroxenes (open circles), alkali amphiboles and sodic-calcic amphiboles (amphiboles $=$ crosses) plotted in Figs. 4, 5 and 6. 1. Aegirine and riebeckite of Pikkukallio, specimen 7-OM, present study. 2. Sodian diopside from gabbro, Halditschokko (Haltia), Enontekiö (Hausen 1942). 3. Sodian diopside from amphibole-pyroxene-albite diabase of Vähä-Kurkkio, Enontekiö (Meriläinen 1961). 4. Aegirines, aegirine-augites, alkali-amphiboles and sodic-calcic amphiboles from the carbonatite and fenites of Sokli, Savukoski (Vartiainen and Woolley 1976 and Vartiainen 1980). 5. Aegirine-augite and sodian diopside from alkaline rocks of Iivaara, Kuusamo (Lehijärvi 1960). 6. Magnesioriebeckite from a shear zone of Puolanka (Laajoki and Ojanperä 1973). 7. Richterite from glimmerite of the carbonatite complex, Siilinjärvi (Puustinen 1972). 8. Arfvedsonite and aegirine from nepheline syenite gneiss (boulder) of Kiihtelysvaara (Eskola and Sahlstein 1930). 9. Ferro-ferribarroisite of Otanmäki (Hytönen and Heikkinen 1966). 
Association (Leake 1978). The mineral is rich in iron and poor in magnesium and its composition is thus quite close to the end member of riebeckite, $\mathrm{Na}_{2} \mathrm{Fe}_{3}^{2+} \mathrm{Fe}_{2}^{3+} \mathrm{Si}_{8} \mathrm{O}_{23}$, written on a waterand halogen-free basis.

The following unit-cell parameters for the riebeckite were calculated from the powder pattern, listed in Table 6: $a=9.840$ (3) $\AA, b=18.078$ (5) $\AA, \mathrm{c}=5.336$ (2) $\AA, \beta=103.79^{\circ}, \mathrm{V}=921.8 \AA^{3}$. The cell data differ slightly from those given by Hoffmann and Katz (1982) for an extrapolated riebeckite end member: $\mathrm{a}=9.822 \AA, \mathrm{b}=18.07$ $\AA, \mathrm{c}=5.334 \AA, \beta=103.52^{\circ}, \mathrm{V}=919.0 \AA^{3}$. The cell dimensions $\mathrm{a}, \mathrm{b}, \mathrm{c}$ and $\mathrm{V}$ of the Pikkukallio

Table 5. Riebeckite, specimen 7-OM, Pikkukallio, Honkamäki, Vuolijoki. Chemical composition, numbers of ions on the basis of 23 oxygens and calculated density. 1. Average of four microprobe analyses $(\mathrm{FeO}=$ total iron). 2. Analysis of column 1, done using the ratio $\mathrm{Fe}^{2+}: \mathrm{Fe}^{3+}=1.48$ (wet analysis). 3. Analysis of column 1, done using the $\mathrm{Fe}_{2} \mathrm{O}_{3}$ and $\mathrm{FeO}$ values obtained in the wet analysis. Wet analysis by Pentti Ojanperä.

\begin{tabular}{|c|c|c|c|c|c|}
\hline & 1 & 2 & & 3 & \\
\hline $\mathrm{SiO}_{2}$ & 48.9 & 48.9 & & 48.9 & \\
\hline $\mathrm{TiO}_{2}$ & 0.8 & 0.8 & & 0.8 & \\
\hline $\mathrm{Al}_{2} \mathrm{O}_{3}$ & 2.8 & 2.8 & & 2.8 & \\
\hline $\mathrm{Fe}_{2} \mathrm{O}_{3}$ & & 16.6 & & 15.3 & \\
\hline $\mathrm{FeO}$ & 37.1 & 22.2 & & 20.5 & \\
\hline $\mathrm{MnO}$ & 1.1 & 1.1 & & 1.1 & \\
\hline $\mathrm{MgO}$ & 0.6 & 0.6 & & 0.6 & \\
\hline $\mathrm{CaO}$ & 1.2 & 1.2 & & 1.2 & \\
\hline $\mathrm{Na}_{2} \mathrm{O}$ & 4.5 & 4.5 & & 4.5 & \\
\hline \multirow[t]{2}{*}{$\mathrm{K}_{2} \mathrm{O}$} & 1.3 & 1.3 & & 1.3 & \\
\hline & 98.3 & 100.0 & & 97.0 & \\
\hline $\mathrm{Si}$ & & $7.51)$ & \multirow{2}{*}{8.00} & \multicolumn{2}{|c|}{$7.66 \times 8.00$} \\
\hline $\mathrm{Al}$ & & 0.49 & & $0.34^{\prime}$ & \\
\hline $\mathrm{Al}$ & & 0.02 & \multirow{4}{*}{5.00} & 0.18 & \multirow{5}{*}{5.00} \\
\hline $\mathrm{Ti}$ & & 0.10 & & 0.10 & \\
\hline $\mathrm{Fe}^{3+}$ & & 1.92 & & 1.81 & \\
\hline $\mathrm{Mg}$ & & 0.13 & & 0.13 & \\
\hline $\mathrm{Fe}^{2+}$ & & 2.83 & \multirow{7}{*}{1.97} & 2.68 & \\
\hline $\mathrm{Fe}^{2+}$ & & 0.02 & & & \multirow{6}{*}{1.90} \\
\hline $\mathrm{Mn}$ & & & & 0.10 & \\
\hline $\mathrm{Mn}$ & & 0.14 & & 0.05 & \\
\hline $\mathrm{Ca}$ & & 0.20 & & 0.21 & \\
\hline $\mathrm{Na}$ & & 1.35 & & 1.38 & \\
\hline $\mathrm{K}$ & & 0.26 & & $0.26 J$ & \\
\hline $\mathrm{D}_{\text {calc. }}$ & & 3.39 & & 3.36 & \\
\hline
\end{tabular}

riebeckite are slightly larger than those of the end member. The expansion of the cell can be attributed to the potassium ion (Table 5), the largest cation present in excess in this mineral. As an example of the expanding effect of the potassium ion on the unit cell dimensions of amphiboles, we refer to a study on the synthesis and crystal chemistry of sodium-potassium richterite (Huebner and Papike 1970).

The following optical properties were recorded for the riebeckite: $\gamma=1.708, b=Y$, $\mathrm{c} \Lambda \mathrm{X}=0^{\circ}-10^{\circ}$; pleochroism: $\mathrm{X}$ dark blue, $\mathrm{Y}$ dark grey-blue, $\mathrm{Z}$ yellow brown; absorption: $\mathrm{Y}>\mathrm{X} \gg \mathrm{Z}$.

The very strong absorption and dispersion of light greatly hinders optical observations and measurements of the riebeckite. The optical

Table 6. X-ray powder pattern of riebeckite from Pikkukallio, Honkamäki, Vuolijoki.

\begin{tabular}{|c|c|c|c|}
\hline hkl & $\mathrm{I} / \mathrm{I}_{0}$ & $d_{\text {meas. }}$ & $\mathrm{d}_{\text {calc. }}$ \\
\hline 110 & 100 & 8.45 & 8.450 \\
\hline 200 & 3 & 4.79 & 4.780 \\
\hline 040 & 14 & 4.52 & 4.520 \\
\hline 131 & 12 & 3.424 & 3.423 \\
\hline 240 & 10 & 3.281 & 3.283 \\
\hline 310 & 63 & 3.137 & 3.137 \\
\hline 221 & 12 & 2.981 & 2.981 \\
\hline 330 & 12 & 2.814 & 2.816 \\
\hline 151$\}$ & 53 & 2778 & $\int 2.729$ \\
\hline 331 & נת & 2.120 & 2.727 \\
\hline 061 & 15 & 2.604 & 2.605 \\
\hline 260 & 11 & 2.546 & 2.549 \\
\hline 202 & 11 & 2.040 & 2.546 \\
\hline 350 & 3 & 2.390 & $\{2.390$ \\
\hline 400$\}$ & $J$ & 2.590 & 2.389 \\
\hline 351 & 13 & 2.334 & 2.335 \\
\hline 171 & 4 & 2.195 & 2.194 \\
\hline 261 & 15 & 2.180 & 2.180 \\
\hline 202 & 7 & 2.080 & 2.080 \\
\hline 351 & 12 & 2.037 & 2.036 \\
\hline 2.10 .0$\}$ & 3 & 1.691 & $\{1.691$ \\
\hline $282 \quad J$ & 3 & 1.051 & $\{1.690$ \\
\hline 461 & 15 & 1.664 & 1.664 \\
\hline $\begin{array}{l}1.11 .0 \\
352\end{array}$ & 5 & 1.619 & $\left\{\begin{array}{l}1.620 \\
1620\end{array}\right.$ \\
\hline $\begin{array}{l}352 \\
153\}\end{array}$ & & & $\begin{array}{r}1.619 \\
1.594\end{array}$ \\
\hline $\left.\begin{array}{l}153 \\
600\end{array}\right\}$ & 12 & 1.594 & $\left\{\begin{array}{l}1.094 \\
1.593\end{array}\right.$ \\
\hline 0.12 .0 & 3 & 1.507 & 1.506 \\
\hline$\overline{6} 61$ & 11 & 1.438 & 1.438 \\
\hline
\end{tabular}




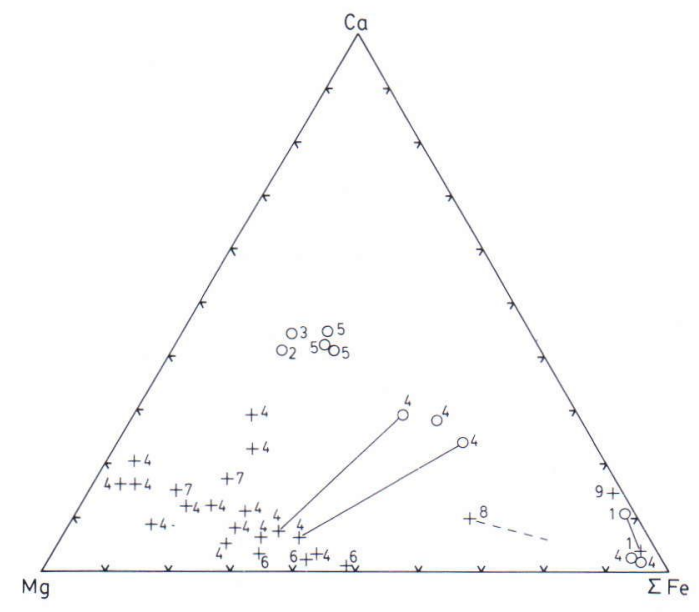

Fig. 5. Plot of aegirine and riebeckite of present study (no. 1) together with other sodic pyroxenes and alkali and sodiccalcic amphiboles from Finland in terms of $\mathrm{Ca}, \mathrm{Mg}$ and total Fe. Pyroxenes=open circles, amphiboles = crosses. Coexisting pyroxene-amphibole pairs are joined by tie lines. The numbers of the plots refer to Fig. 4 .

properties listed are therefore incomplete. On the other hand, it is known that very small variations in refractive indices within the grains of a single thin section can produce a dramatic

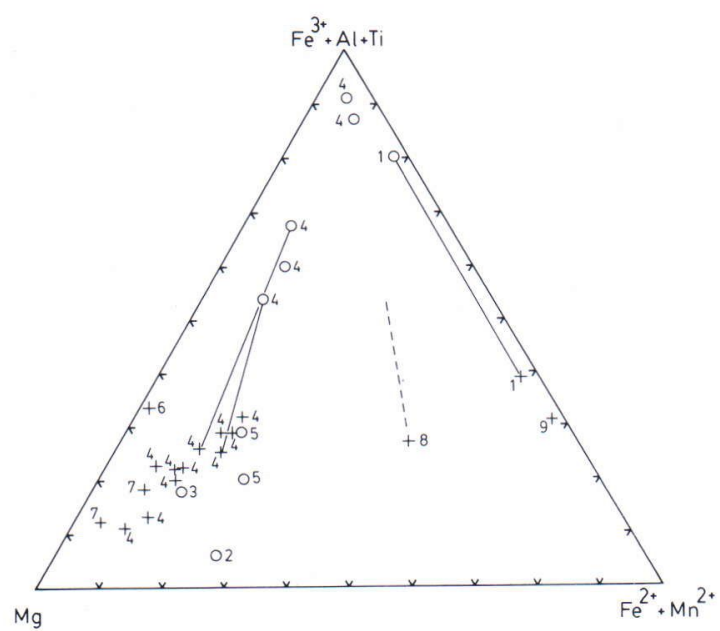

Fig. 6. Relation between octahedrally coordinated $\mathrm{Mg}$, $\left(\mathrm{Fe}^{3+}+\mathrm{Al}+\mathrm{Ti}\right)$ and $\left(\mathrm{Fe}^{2+}+\mathrm{Mn}\right)$ of aegirine and riebeckite of present study (no. 1) together with other sodic pyroxenes (open circles) and alkali and sodic-calcic amphiboles (amphiboles $=$ crosses) from Finland. Coexisting mineral pairs are connected by tie-lines. The numbers of the plots refer to variation in optical orientation (Borg 1967). Some conflicting observations of the optical orientation suggest that the optical orientation of this riebeckite varies from grain to grain, even within a single thin section.

For comparison and to illustrate the chemical composition the riebeckite of Pikkukallio has been plotted in terms of $\mathrm{Ca}, \mathrm{Mg}$ and total $\mathrm{Fe}$ (Fig. 5) and in terms of octahedrally coordinated $\left(\mathrm{Fe}^{3+}+\mathrm{Al}+\mathrm{Ti}\right), \quad \mathrm{Mg}$ and $\left(\mathrm{Fe}^{2+}+\mathrm{Mn}\right)$ (Fig. 6) together with some other alkali amphiboles, sodic-calcic amphiboles and sodic pyroxenes from Finland. Triangular diagrams, e.g., those by Foster for trioctahedral micas (1960) and by Simonen and Vorma for amphibole and biotite from rapakivi (1969), have been used to illustrate the proportions of the octahedrally coordinated cations.

The sodic-calcic amphibole occurring as fissure filling in alkali granite or alkali gneiss at the western foot of the adjacent Otanmäki hill has been described in a paper by Hytönen and Heikkinen (1966). The amphibole was called an alkali amphibole of intermediate composition slightly closer to the alkali amphiboles than the calcic amphiboles. For the present study this amphibole is renamed ferro-ferri-barroisite, using the nomenclature of amphiboles presented by the subcommittee on amphiboles of the International Mineralogical Association (op. cit.).

The riebeckite of the gneissose granite described by Pääkkönen (1956) from Katajakangas on the western side of the Otanmäki hill and, hence, not far from the outcrop studied by Hytönen and Heikkinen ( $o p$. cit.), has not been plotted in Figs. 5 and 6 because no chemical data were given. However, on the basis of the refractive indices listed, this alkali amphibole of Pääkkönen seems to be close to the end member riebeckite.

Examination of Figs. 5 and 6 reveals that the riebeckite of Pikkukallio and the ferro-ferribarroisite of the adjacent Otanmäki are richer in iron and poorer in magnesium than the other 
alkali amphiboles and sodic-calcic amphiboles from Finland. In the other amphiboles magnesium predominates over iron, except in the arfvedsonite from the nepheline syenite gneiss of Kiihtelysvaara (Eskola and Sahlstein 1930; No. 8 in Figs. 5 and 6).

\section{Chemical relationship between aegirine and riebeckite}

The present authors know of three occurrences in Finland where alkali pyroxene and alkali amphibole coexist: in the nepheline syenite gneiss of Kiihtelysvaara (Fig. 4, no. 8, boulder) (Eskola and Sahlstein 1930), in the carbonatite and fenites of Sokli, Savukoski (Fig. 4, no. 4) (Vartiainen and Woolley 1976 and Vartiainen 1980 ) and in the alkali gneiss of the present study (Fig. 4, no. 1).

Figs. 5 and 6 illustrate the chemical relationship between the aegirine-riebeckite pair of Pikkukallio and the other sodic pyroxenes and alkali and sodic-calcic amphiboles from Finland. Coexisting pyroxene-amphibole pairs are joined by tie-lines. As the aegirine of the nepheline syenite gneiss of Kiihtelysvaara (Eskola and Sahlstein, op. cit.) was not chemically analysed and thus its precise plot is unknown, the tie-line connecting the plot of arfvedsonite (no. 8) towards the plot of acmite, $\mathrm{NaFe}^{3+}$ $\mathrm{Si}_{2} \mathrm{O}_{6}$ (the $\mathrm{Fe}$ corner in Fig. 5 and the $\mathrm{Fe}^{3+}+\mathrm{Al}+\mathrm{Ti}$ corner in Fig. 6, respectively) is shown as a dashed line.

Examination of Figs. 5 and 6 reveals that the aegirine-riebeckite pair of Pikkukallio differs in composition from the pyroxene-amphibole pairs of Sokli: both the pyroxene and the amphibole of Pikkukallio are richer in iron and poorer in magnesium and calcium than are the members of the two pyroxene-amphibole pairs of Sokli.

Figure 6 also illustrates the relative state of oxidation of iron: in the pyroxene-amphibole pairs the pyroxene is more oxidized than the amphibole.

The mineral pair aegirine-riebeckite is known to be rather common in peralkaline gneisses from numerous localities of the world over (Floor 1974). However, further comparisons with other occurrences are beyond the scope of the present study.

\section{Age of the Honkamäki granite}

The age of the zircon from the Honkamäki granite, about 600 metres south of the Pikkukallio outcrop (Fig. 2), has been radiometrically determined at the isotope geology laboratory of the Geological Survey of Finland and the results have been published in two papers (Marmo et al. 1966 and Talvitie and Paarma 1980). The age was later checked from two zircon fractions, preleached in hydrofluoric acid. The new results, together with the earlier ones, are summarized in Table 7 and plotted in the concordia diagram in Figure 7.

Examination of Figure 7 reveals that the five zircon fractions form an excellent linear array, having an upper intercept age of $2019 \pm 3 \mathrm{Ma}$ (2

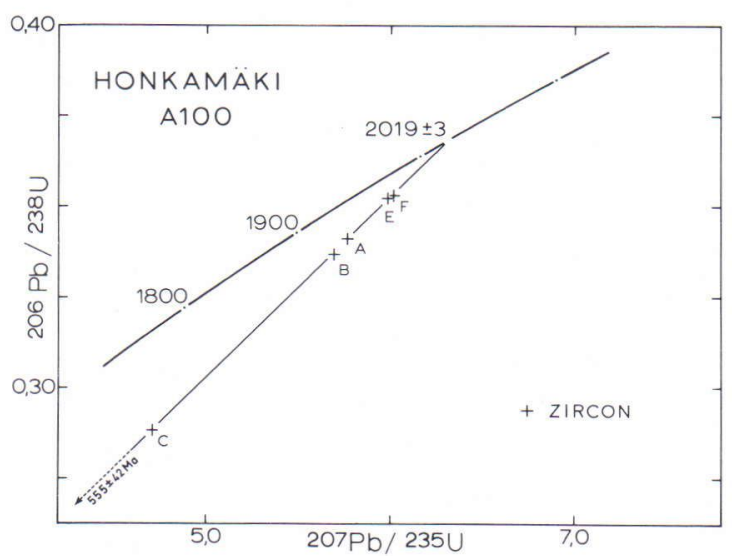

Fig. 7. Concordia diagram for zircons of the Honkamäki granite, Vuolijoki. 
Table 7. Uranium-lead isotopic data and radiometric ages for zircons of the Honkamäki granite, Vuolijoki. Decay constants: Jaffey et al. 1971.

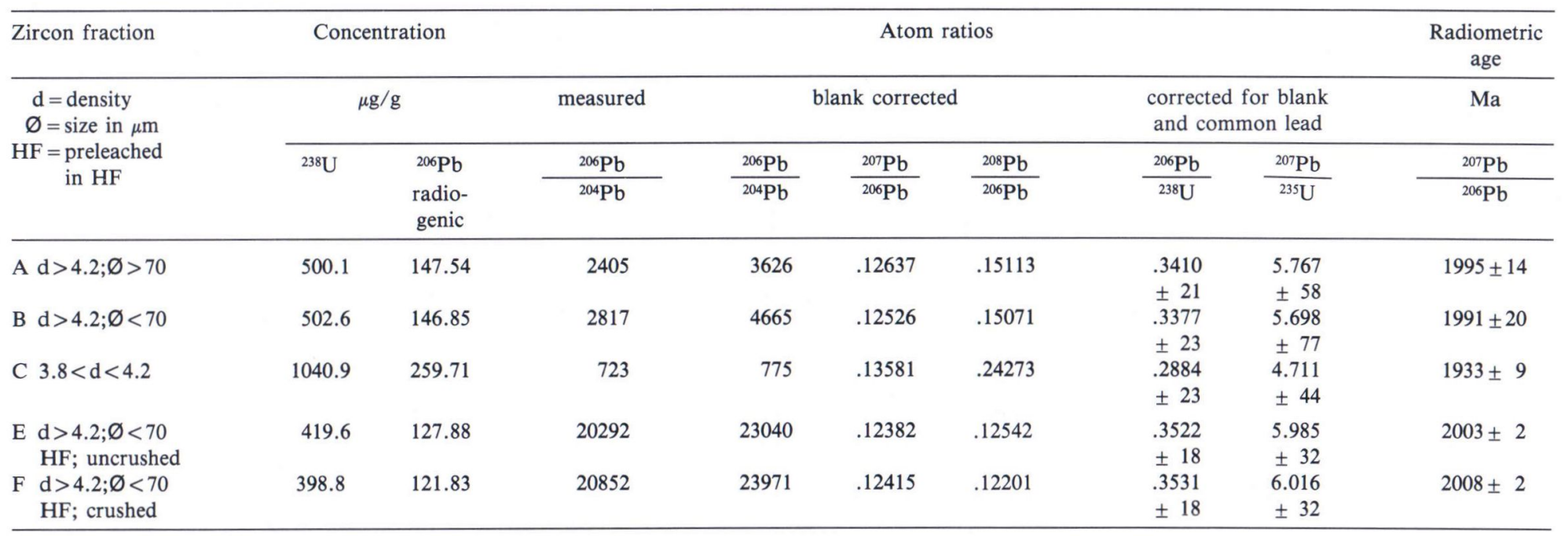


sigma) and a lower intercept with concordia at $555 \pm 42$ Ma (2 sigma).

There is a direct correspondence between the uranium content and the degree of discordance (Table 7 and Fig. 7). The most concordant fractions, $\mathrm{E}$ and $\mathrm{F}$, were preleached in cold $4 \%$ hydrofluoric acid in an ultrasonic bath for ten minutes. The uranium content is lowest in these fractions, but the most distinctive feature is that the common lead content is drastically lower than in other fractions.

Both the Honkamäki granite and the alkali gneiss of the present study are varieties of the alkali gneiss of the Honkamäki-Otanmäki area. The age of $2019 \mathrm{Ma}$ is quite close to the $2065 \mathrm{Ma}$ of the gabbros of Otanmäki and Vuorokas (Talvitie and Paarma, op. cit.) (Fig. 1) but is distinctly older than the c. $1900 \mathrm{Ma}$ of the synorogenic Svecokarelidic plutonic rocks.

\section{References}

Bence, A. E. \& Albee, A. L., 1968. Empirical correction factors for the electron microanalysis of silicates and oxides. J. Geol. 76, 382-403.

Borg, I. Y., 1967. Optical properties and cell parameters in the glaucophane-riebeckite series. Contr. Mineral. and Petrol. 15, 67-92.

Carmichael, I. S. E., 1962. Pantelleritic liquids and their phenocrysts. Min. Mag. 33, 86-113.

Eskola, Pentti \& Sahlstein, Th. G., 1930. On astrophyllitebearing nephelite syenite gneiss, four:d as a boulder in Kiihtelysvaara, eastern Finland. C.R. Soc. géol. Finlande 3 (also Bull. Comm. Géol. Finlande 92), 77-88.

Floor, P., 1974. Alkaline gneisses. In the Alkaline Rocks, edited by H. Sørensen. John Wiley and Sons, London, New York, Sydney, Toronto, 124-142.

Foster, Margaret D., 1960. Interpretation of the composition of trioctahedral micas. U.S. Geol. Survey Prof. Paper 354-B, 25 and 33.

Hausen, H., 1942. Das Halditjokkomassiv. Ein phacolitischer Intrusionskörper basischer Differentiate im Abschnitt Finnlands der Kaledoniden. Acta Acad. Aboensis, Ser. Math.-Phys. vol. 13, 14, 56-58.

Hoffmann, Christoph \& Katz, Kerstin, 1981. Trend surface analysis of some physical properties of alkali (sodic) amphiboles. Lithos 15, 17-25.
Acknowledgements. The authors are grateful to the following members of Rautaruukki Oy: Mr. Ole Lindholm, for fruitful discussions and permission to use the geological map of the Otanmäki region, Mr. Risto Anttonen, and Mrs Mirja Jaanus-Järkkälä for assistance in the field in the Honkamäki area, and to Dr. Rolf Rosenberg of the Reactor Laboratory, Technical Research Centre of Finland, for the instrumental neutron activation analysis, and to the following staff members of the Geological Survey of Finland: the late Mr. Aulis Heikkinen and the late Mr. Pentti Ojanperä for the wet chemical analyses, Mrs. Maija HagelBrunnström and Mr. Väinö Hoffrén for the XRF analyses, Mrs. Meeri Wallgren for the AAS analyses, Mr. Ari Puisto for the optical spectrometric analyses, Dr. Olavi Kouvo for information about the age of the Honkamäki granite, Mrs. Mirja Saarinen for separation of the minerals, Mr. Toivo Alanen for preparation of the polished thin sections and Mrs. Ritva Forsman for drawing the maps and diagrams.

Professor Atso Vorma and Mr. Pekka Kallio read the manuscript and offered constructive criticism.

Huebner, J. Stephen \& Papike, J. J., 1970. Synthesis and crystal chemistry of sodium-potassium richterite, ( $\mathrm{Na}$, K) $\mathrm{NaCaMg}_{5} \mathrm{Si}_{8} \mathrm{O}_{22}(\mathrm{OH}, \mathrm{F})_{2}$ : a model for amphiboles. Am. Mineral 55, 1973-1992.

Hytönen, Kai \& Heikkinen, Aulis, 1966. Alkali amphibole of Otanmäki, Finland. C. R. Soc. géol. Finlande (also Bull. Comm. Géol. Finlande 222) 38, 145-156.

Jaffey, A. H.; Flynn, K. F.; Glendenin, L. E.; Bentley, W. C. \& Essling, A. M., 1971. Precision measurement of half lives and specific activities of ${ }^{235} \mathrm{U}$ and ${ }^{238} \mathrm{U}$. Phys. Rev. 4, 1889-1906.

Laajoki, Kauko \& Ojanperä, Pentti, 1973. Magnesioriebeckite and penninite from a shear zone in Puolanka, NE Finland. Bull. Géol. Soc. Finland 45, 143-153.

Leake, Bernard E., 1978. Nomenclature of amphiboles. Am. Min. 63, 1023-1052.

Lehijärvi, Mauno, 1960. The alkaline district of Iivaara, Kuusamo, Finland. Bull. Comm. Géol. Finlande 185, 48-50.

Lindholm, Ole \& Anttonen, Risto, 1980. Geology of the Otanmäki mine. In 26th International Geological Congress. II-Precambrian ore deposits in Sweden and Finland. Häkli, T. A. (editor): Precambrian ores of Finland; Guide to excursions $078 \mathrm{~A}+\mathrm{C}$ part 2 (Finland), 191-199.

Marmo, V.; Hoffrén, V.; Hytönen, K.; Kallio, P.; Lindholm, O. \& Siivola, J., 1966. On the granites of Honka- 
mäki and Otanmäki, Finland. Bull. Comm. Géol. Finlande 221, 34 pp.

Meriläinen, Kauko, 1961. Albite diabases and albitites in Enontekiö and Kittilä, Finland. Bull. Comm. Géol. Finlände 195, 43-44.

Nolan, J., 1969. Physical properties of synthetic and natural pyroxenes in the system diopside-hedenbergiteacmite. Min. Mag. 37, 216-229.

Pääkkönen, Veikko, 1956. Otanmäki, the ilmenite-magnetite ore field in Finland. Bull. Comm. Géol. Finlande $171,19-20$.

Puustinen, Kauko, 1972. Richterite and actinolite from the Siilinjärvi carbonatite complex, Finland. Bull. Geol. Soc. Finland 44, 83-86.

Simonen, Ahti \& Vorma, fitso, 1969. Amphibole and biotite from rapakivi. Bull. Comm. Géol. Finlande 238, $19-25$.

Streckeisen, A., 1974. Classification and nomenclature of plutonic rocks. Recommendations of the IUGS Subcommission on the systematics of igneous rocks. Geol. Rundschau 63, 733-786.

Talvitie, J. \& Paarma, H., 1980. Precambrian basic magmatism and the Ti-Fe ore formation in central and northern Finland. In Siivola, Jaakko (editor): Metallogeny of the Baltic Shield, proceedings of the symposium held in Helsinki, Finland, June 12-21, 1978. Geol. Surv. Finland Bull. 307, 98-107.

Taylor, S. R., 1964. Abundance of chemical elements in the continental crust: a new table. Geochim. et Cosmochim. Acta 28, 1273-1285.

Vartiainen, Heikki, 1980. The petrography, mineralogy and petrochemistry of the Sokli carbonatite massif, northern Finland. Geol. Surv. Finland Bull. 313, 69-79.

Vartiainen, Heikki \& Woolley, Alan R., 1976. The petrography, mineralogy and chemistry of the fenites of the Sokli carbonatite intrusion, Finland. Geol. Surv. Finland Bull. 280, 39-53.

Vinogradov, P. A., 1962. Average contents of chemical elements in the principal types of igneous rocks of the earth's crust. Geochemistry 7, 641-663.

Wilkman, W. W., 1929. Suomen geologinen yleiskartta. Kivilajikartta. General Geological Map of Finland. PreQuaternary rocks. Lehti-Sheet-(C 4)-Kajaani. 1 : 400 000. Geological Commission of Finland. Helsinki (Now: Geological Survey of Finland. Espoo).

—, 1931. Suomen geologinen yleiskartta. Kivilajikartan selitys. General Geological Map of Finland. Pre-Quaternary rocks. Lehti C 4, Kajaani, p. 148. Geological Commission of Finland, Helsinki (Now: Geological Survey of Finland, Espoo). 